\title{
Economic Evaluation of Wastewater Treatment System Based on Recovery Characteristics of Oil and Suspended Solids by Filtration
}

\author{
Eriko ANKYU*1†, Toshihiko OTSUKA ${ }^{* 1}$, and Ryozo NOGUCHI ${ }^{2}$ \\ (Received October 5, 2016)
}

\begin{abstract}
Filtration experiments were conducted using artificial wastewater at $20^{\circ} \mathrm{C}$ and $60{ }^{\circ} \mathrm{C}$ to explain the relationship between the separation ability of oil-water separation equipment and the recovery rate of suspended solids (SS) recovery equipment for oil concentrations. Based on the characteristics of oil and SS explained by the filtration experiments, an economic evaluation method for a wastewater treatment system was proposed for two cases: using oil-water separation equipment without SS recovery equipment (single use) and using oil-water separation equipment with SS recovery equipment (combination use) using Separative Work Unit (SWU). The separation ability of oil-water separation equipment could determine the required recovery rate of SS recovery equipment. The SWU for combination use at $20^{\circ} \mathrm{C}$ and $60^{\circ} \mathrm{C}$ was higher than the SWU for single use. The SWU for combination use at $60^{\circ} \mathrm{C}$ was higher than that at $20^{\circ} \mathrm{C}$. At $60^{\circ} \mathrm{C}$, combination use increased the SWU by $562 \mathrm{JPY} /$ day (treatment amount 3,000 L/day) compared to single use, at $45 \%$ separation ability of the oil-water separation equipment according to the results of our filtration experiments.
\end{abstract}

水温 $20^{\circ} \mathrm{C}$ と $60^{\circ} \mathrm{C}$ 模擬排水を用いて濾過実験をおこない, 油の濃度に対する油水分離装置の分離性能と SS 回収装置の回収 率の関係を明らかにした。濾過実験で明らかになった油と SS の濾過特性にもとづき, 油水分離装置を用いて SS 回収装置を用いな い単独使用 (single use) と, 油水分離装置とSS 回収装置を使用する併用使用 (combination use) の2条件に対して, 分離作業 量 (SWU) を用いて排水処理システムの経済性評価手法の提案を行った。油水分離装置の分離性能が決まることによって, 必要 なSS 回収装置の回収率が決定された。水温 $20^{\circ} \mathrm{C}$ と $60^{\circ} \mathrm{C}$ に执ける併用使用の分離作業量は, 単独使用の分離作業量よりも高い

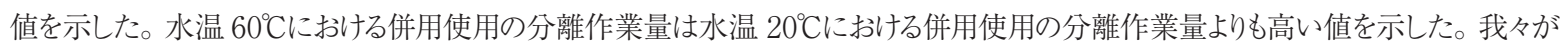
行った濾過実験実験での水温 $60^{\circ} \mathrm{C}$ 条件に执いて, 併用使用では, 単独使用に比べて油水分離性能が $45 \%$ が562 円/日（処理量 $3,000 \mathrm{~L} /$ 日）上昇した。

\section{Key Words}

Economic evaluation, Filtration, Oil-water separation, Separative Work Unit, Suspended solids,

Wastewater treatment

\section{Introduction}

Wastewater from food processing factories, restaurants, and food shops includes large amounts of animal and vegetable oil. This oil causes various problems for wastewater treatment, such as decreasing the efficiency of the wastewater treatment facility, and increasing running costs of the facility ${ }^{11}$. Grease traps for collecting oil in wastewater are typically set in food processing factories, restaurants, and food shops in Japan. However, they are

\footnotetext{
※1 Graduate School of Life and Environmental Sciences, University of Tsukuba

1-1-1, Tennodai, Tsukuba, Ibaraki 305-8577, Japan

※2 Faculty of Life and Environmental Sciences, University of Tsukuba

1-1-1, Tennodai, Tsukuba, Ibaraki 305-8577, Japan

$\dagger \quad$ Corresponding author: eri.an9193@gmail.com
}

not effective for wastewater that includes a large amount of oil, and wastewater that still contains a little amount of oil overflowed downstream. Wastewater flowing into river bodies causes odor problems and water contamination. Wastewater flowing into sewage system is one of the causes of blocked drains and pipes. In some cases, consolidated oil forms oil balls that draft into the sea ${ }^{2)}$. Moreover, running cost and time for wastewater treatment facilities increase if wastewater includes a large amount of oil. Although food processing factories, restaurants, and food shops are allowed to release only a limited concentration of oil in wastewater below the effluent standard, set by the Water Pollution Control Law in Japan, they still release wastewater including a large amount of oil.

There are many studies on using microorganisms 
in wastewater treatment by introducing them into grease

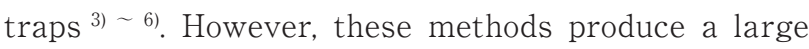
amount of residue, increasing the initial and running cost of underground grease traps, and slowing the speed of the treatment process. Using oil-water separation equipment for recovering oil from wastewater before releasing it into the treatment facility that includes a grease trap increases the efficiency of the treatment facility, reduces initial and running costs, and makes it possible to reuse the recovered oil as an energy resource ${ }^{7)}{ }^{8)}$. In a previous study ${ }^{9)}$, an economic evaluation of installing oil-water separation equipment into a wastewater treatment system in a food processing factory was conducted.

Wastewater from food processing factories, restaurants, and food shops includes not only oil but also large volumes of suspended solids (SS) such as food residue, composed mainly of protein and starch. If high performance oil and SS recovery can be achieved, the total workload and running costs of wastewater treatment would be dramatically reduced. Furthermore, recovered oil and SS can serve as significant sources of additional profit if oil and SS can be collected with no chemical change. Thus, the separation ability of oil-water separation equipment and the recovery rate of SS recovery equipment affect the economics of the treatment process.

This study aims to evaluate the economics of installing oil-water separation and SS recovery equipment on a wastewater treatment system using the recovery characteristics of oil and SS by filtration and Separative Work Unit (SWU).

First, filtration experiments representing SS recovery equipment were conducted using artificial wastewater to identify the relationship between the separation ability of oil-water separation and the recovery rate of SS recovery equipment for oil concentration. Since high performance SS recovery can be achieved empirically by reducing oil concentration in wastewater through filtration, artificial wastewater with changing concentrations of oil and SS was used in the filtration experiments to calculate the recovery rate of oil and SS. Second, an economic evaluation method was proposed to evaluate the installation of oil-water separation and SS recovery equipment on a wastewater treatment system based on a previous study ${ }^{9}$.

\section{Materials and Methods}

2.1 Filtration experiments for recovery characteristics of oil and SS using different oil concentrations of artificial wastewater

The concept of oil-water separation and SS recovery in this study is illustrated in Fig. 1. Oil-water separation equipment recovered oil from oil- and SS-containing wastewater. Next, SS recovery equipment recovered SS from oil-removed water. Oil- and SS-removed water was then treated at the wastewater treatment facility. The study site of evaluation was a fictional family restaurant or a food shop (the model restaurant) that discharges wastewater including large amounts of oil and SS.

Oil-water separation equipment assumed in this study was operated based on the specific gravity of oil and water and on the wastewater flow rate inside the equipment, without chemical or biological treatment. As a result, there were no water quality changes. Filtration equipment was selected to act as a SS recovery equipment after oil-water separation and before wastewater treatment, because recovering SS upstream of a wastewater treatment facility decreases the cost and size of the facility and increases the possibility of using recovered SS as a recycled resource. A pouched grid mesh was used as a SS recovery equipment.

It is not proper to use wastewater from actual food processing factories, restaurants, and food shops in the filtration experiments because there is a wide range of elements including the components in actual wastewater, and temperature and flow velocity of actual wastewater. In this study, filtration results of artificial wastewater

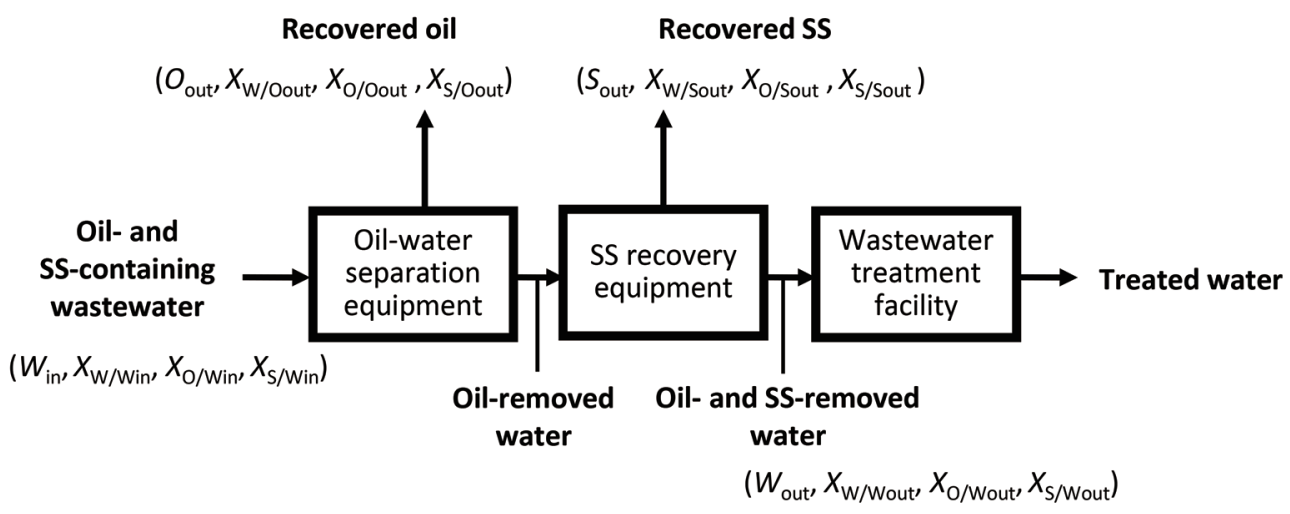

Fig. 1 Concept of oil-water separation and SS recovery in a wastewater treatment system 
containing vegetable oil and flour (as SS) were used for the economic evaluation. To comparison, actual wastewater from the cafeteria of the University of Tsukuba in December 2016 was also used.

Filtration experiments using artificial wastewater with varying concentrations of oil and SS as oil-removed water were conducted to identify the relationship between the separation ability of oil-water separation equipment and the recovery rate of SS recovery equipment. The mesh had 0.44-mm openings and a thread diameter of $0.20 \mathrm{~mm}$, similar to the ones installed on food preparation facilities. One sheet of mesh cut into roughly 40-mm squares was used in each filtration trial. The filtration unit including the mesh sheet is shown in Fig. 2. A filtration tray (inner diameter $54.0 \mathrm{~mm}$, hole diameter $21.5 \mathrm{~mm}$, height 20.0 $\mathrm{mm})$ was placed on the mesh sheet. The effective filtration area was $3.64 \times 10^{2} \mathrm{~mm}^{2}$. The inlet velocity of artificial wastewater was $0.017-0.020 \mathrm{~L} / \mathrm{s}$, which ensured constant velocity and inlet time.

Artificial wastewater was composed of water, sunflower oil as oil, and flour as SS. Flour was selected because it has inconsistent particle size $\left(5-100 \mu \mathrm{m}^{10)}\right)$ and is mainly composed of protein and starch.

Experimental conditions consisted of 42 combinations of six oil concentrations $(0.5,1.0,1.5,2.0,2.5$, and $3.0 \mathrm{~g} / \mathrm{L})$ and seven SS concentrations (0.5, 1.0, 1.5, 2.0, 2.5, 3.0, and 3.5 $\mathrm{g} / \mathrm{L})$. Maximum values were determined based on the data collected during a field investigation.

Variation in mesh weight before and after drying over one day was measured. The recovery rate of oil and SS by filtration was expressed as the variation in mesh weight divided by the sum of sunflower oil and flour in artificial wastewater (eq. (1)), where $R$ is the recovery rate of oil and SS by filtration, $\Delta W_{\mathrm{m}}$ is the variation in mesh weight $\left(W_{\mathrm{m}}\right)$ before and after filtration and drying, and $W_{\text {oil }}$ and $W_{\mathrm{sS}}$ are the weight of input oil and SS in artificial wastewater, respectively.

$$
R=\frac{\Delta W_{\mathrm{m}}}{W_{\text {oil }}+W_{\mathrm{SS}}}
$$

In this simulation, the recovery rate of SS recovery equipment was measured for a mixture of oil and SS, because it is difficult to separate oil and SS perfectly. However, recovered SS could be used as a valuable resource if SS recovery equipment could separate oil and SS perfectly that would decrease the amount of SS and the treatment costs.

Drinking water as a base solvent was heated to $20^{\circ} \mathrm{C}$ to represent ordinary wastewater and to $60^{\circ} \mathrm{C}$ to represent hot wastewater for the investigation of the effect of wastewater heating. The process of creating artificial wastewater is described in Fig. 3; $1 \mathrm{~L}$ of drinking water was heated to the target temperature. The appropriate

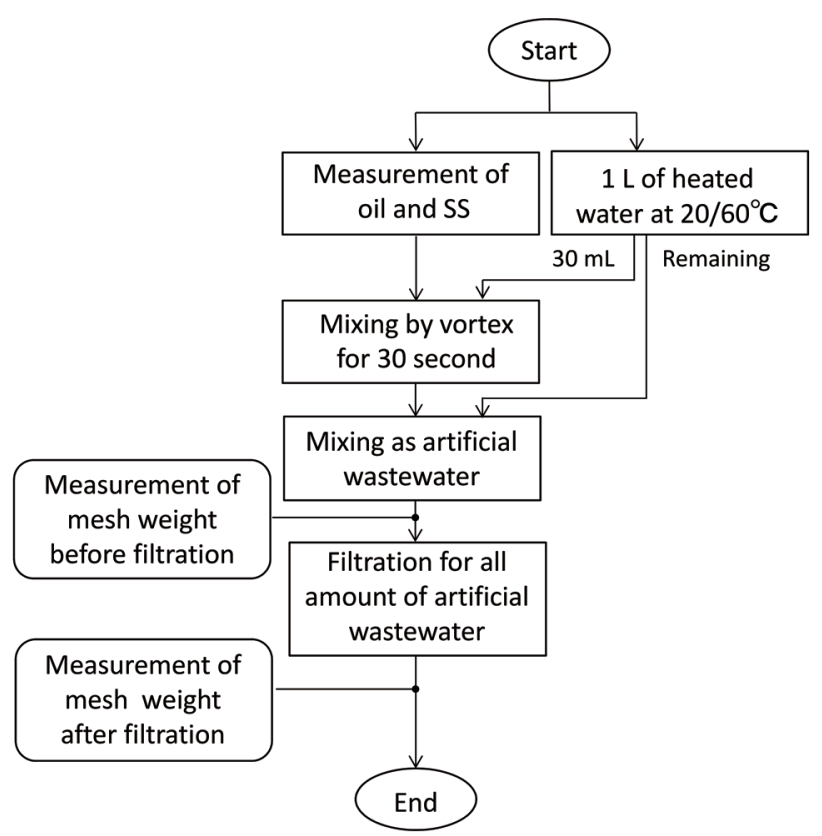

Fig. 3 Procedure of filtration experiments including the preparation of artificial wastewater

\section{Cross section drawing of filtering unit Picture of filtering unit}

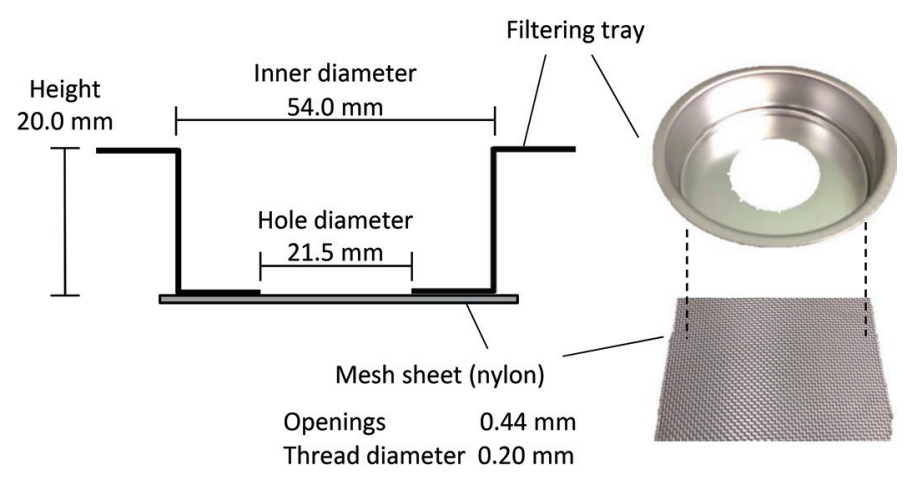

Fig. 2 Filtration unit used in filtration experiments 
concentrations of sunflower oil and flour were measured and put into a centrifuge tube. Heated drinking water $(30 \mathrm{~mL})$ was added to the tube, which was stirred by a vortex mixer for $30 \mathrm{~s}$. The stirred mixture and the remaining heated drinking water were added to a mixing container to create artificial wastewater. Filtration through the mesh sheet was conducted immediately before artificial wastewater could settle out as sediment.

\subsection{Evaluation of oil-water separation and SS recovery}

Wastewater from the model restaurant included vegetable oil and food residue such as protein, representing oil and SS in the filtration experiments, respectively. The amount of wastewater released from the restaurant was $3 \mathrm{~m}^{3}$ day, the concentration of n-hexanes that represented oil concentration was $19,000 \mathrm{mg} / \mathrm{L}$, and SS concentration was $1,100 \mathrm{mg} / \mathrm{L}$.

Fig. 1 shows the concept of the oil-water separation and SS recovery equipment in a restaurant. The oil-water separation equipment separates recovered oil and oilremoved water midstream from the oil- and SS-containing wastewater upstream. The SS recovery equipment separates the recovered SS and oil- and SS-removed water downstream from the oil-removed water midstream. The economic value of the recovered oil, the recovered SS, the oil- and SS-removed water, and the oil- and SScontaining wastewater depends on their volumes and purity (concentration) levels.

Based on a previous study ${ }^{9)}$ where $W_{\text {in }}\left[\mathrm{kg} /\right.$ day], $O_{\text {out }}$ [kg/day], $S_{\text {out }}[\mathrm{kg} / \mathrm{day}]$, and $W_{\text {out }}[\mathrm{kg} /$ day $]$ are the amount of the oil- and SS-containing wastewater per day, the recovered oil per day, the recovered SS per day, and the oil- and SS-removed water per day, respectively. $X_{\mathrm{W} / \text { Win }}[-]$, $X_{\mathrm{W} / \text { oout }}[-], X_{\mathrm{W} / \text { Sout }}[-]$, and $X_{\mathrm{W} / \text { Wout }}[-]$ are defined as the water mixing ratios in: the oil- and SS-containing wastewater, the recovered oil, the ecovered SS, and the oil- and SS-removed water, respectively. $X_{\mathrm{O} / \text { Win }}$ [-], $X_{\mathrm{O} / \text { oout }}[-], X_{\mathrm{O} / \text { Sout }}$ [-], and $X_{\mathrm{W} / \text { oout }}$ [-] $^{-}$ are defined as the oil-mixing ratios in: the oil- and SScontaining wastewater, the recovered oil, the recovered $\mathrm{SS}$, and the oil- and SS-removed water, respectively. $X_{\mathrm{S} / \text { Win }}$

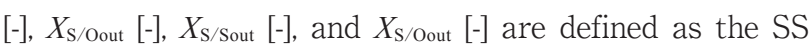
mixing ratios in: the oil- and SS-containing wastewater, the recovered oil, the recovered SS, and the oil- and SSremoved water, respectively. The relationship between these variables is expressed by the following equations.

$$
\begin{aligned}
& W_{\text {in }}=O_{\text {out }}+S_{\text {out }}+W_{\text {out }} \\
& O_{\text {out }} \cdot X_{i / \text { Oout }}+W_{\text {out }} \cdot X_{i / \text { Sout }}+W_{\text {out }} \cdot X_{i / \text { Wout }}=W_{\text {in }} \cdot X_{i / \text { Win }}
\end{aligned}
$$$$
X_{\mathrm{W} / j}+\mathrm{X}_{\mathrm{O} / j}+\mathrm{X}_{\mathrm{S} / j}=1
$$

where $i=\mathrm{W}, \mathrm{O}, \mathrm{S}$ and $j=W_{\text {in }}, O_{\text {out }}, W_{\text {out }}$ are assumed to be true.

\subsection{Value Function and Separative Work Unit}

The SWU is a scale of treatment ability of a separation process and is widely used in the field of nuclear power engineering amongst others ${ }^{11)} \sim 13$ ). A value function $(\mathrm{VF})$ is used to calculate SWU and to convert concentration $X$ to an economic value. SWU is equal to the difference between the total economic value of each substance obtained after separation and the value of mixture before separation. In this study, SWU is considered as the difference between total economic value of the oil-removed water, the recovered oil, and the recovered SS and of the oil- and SS-containing wastewater. Each economic value was calculated by multiplying VF [JPY/kg] by the amount of target substance [kg].

Based on a previous study ${ }^{9}$, the VF of oil-water separation and SS recovery in the model restaurant should be defined for each product with a single unit. Then, $f\left(\mathrm{X}_{\mathrm{O} / \text { Oout }}\right)[\mathrm{JPY} / \mathrm{kg}], g\left(X_{\mathrm{W} / \mathrm{Wout})}\right)[\mathrm{JPY} / \mathrm{kg}], i\left(X_{\mathrm{S} / \mathrm{Sout}}\right)[\mathrm{JPY} / \mathrm{kg}$, and $h\left(X_{\mathrm{W} / \mathrm{Win}}\right)[\mathrm{JPY} / \mathrm{kg}]$ are assumed to be the VFs of the recovered oil, the oil- and SS-removed water, the recovered SS, and the oil- and SS-containing wastewater, respectively The VFs were determined based on the field investigation at a food processing factory, restaurant, and food shops. The initial and running costs of the oil-water separation and SS recovery equipment were included in $g\left(X_{\mathrm{W} / \mathrm{Wout}}\right)$, the $\mathrm{VF}$ of the oil- and SS-removed water.

Daily SWU in the model restaurant, $\delta U_{s s}$, was defined by eq. (5). A positive value of $\delta U_{s s}$ means that profit is generated by separation and a negative value indicates that a cost is incurred by separation.

$$
\begin{aligned}
\delta U_{s s}=O_{\text {out }} f\left(X_{\mathrm{O} / \text { /out }}\right)+W_{\text {out }} \cdot g & \left.X_{\mathrm{W} / \text { Wout }}\right) \\
& +S_{\text {out }} \cdot i\left(X_{\mathrm{S} / \text { /out }}\right)-W_{\text {in }} \cdot h\left(X_{\mathrm{W} / \mathrm{Win}}\right)
\end{aligned}
$$

In this study, two cases of an economic evaluation were calculated: $\delta U_{s s}$, where the model restaurant installed both oil-water separation and SS recovery equipment (SWU for combination use); and $\delta U_{s}$, where the model restaurant installed oil-water separation equipment without SS recovery equipment (SWU for single use) ${ }^{9}$.

As the recovered oil is sold as fuel, the VF of the recovered oil, $f\left(X_{\mathrm{O} / \mathrm{Oou}}\right)$, is determined by the heating value and is expressed as follows.

$$
f\left(X_{\mathrm{O} / \text { oout }}\right)=V_{\text {heat }} \cdot\left(X_{\mathrm{O} / \text { Oout }} \cdot H_{\text {oil }}+X_{\mathrm{S} / \text { Oout }} \cdot H_{\mathrm{SS}}-X_{\mathrm{w} / \text { out }} \cdot H_{\text {wat }}\right)
$$

where $V_{\text {heat }}[\mathrm{JPY} / \mathrm{J}]$ is the conversion factor from the heating value to the economic value. $H_{\text {oil }}[\mathrm{J} / \mathrm{kg}]$ and $H_{\mathrm{ss}}[\mathrm{J} / \mathrm{kg}]$ are the heating values of oil and SS, and $H_{\text {wat }}[\mathrm{J} / \mathrm{kg}]$ is the heat of vaporization for water.

In some cases, the recovered SS can be collected as a valuable resource. However, this study assumed that the recovered SS was collected as industrial waste because it also included oil. Below 85\% water content, the collecting 
cost represented the VF of the recovered SS, $i\left(X_{\mathrm{S} / \text { sout }}\right)$ [JPY/ $\mathrm{kg}$ ], was determined by the amount of industrial waste, as follows.

$$
i\left(X_{\mathrm{S} / \text { sout }}\right)=-C_{\text {ind }}
$$

where $C_{\text {ind }}[\mathrm{JPY} / \mathrm{kg}]$ is the collecting cost of the industrial waste.

Wastewater treatment facility treats some components such as BOD, COD, n-hexanes, SS, T-N, and T-P at the same time ${ }^{14)}$. The initial cost, the running cost, and the size of a wastewater treatment facility were determined by the type and amount of these components in wastewater ${ }^{7}$. Especially, n-hexanes as oil influence the cost and the size of a wastewater treatment facility ${ }^{15)}$. The initial and running costs of a wastewater treatment facility are traditionally determined by the daily allowable amount of wastewater because the treatment facility can only treat oil- and SS-free or low oil- and SS-containing wastewater, rather than wastewater containing high levels of oil as in the case of the model restaurant. Therefore, the standard costs of a wastewater treatment facility for oiland SS-containing wastewater are not clear but can be determined by a facility scale for the maximum permissible concentrations of n-hexanes as oil, $\mathrm{N}[\mathrm{kg} / \mathrm{L}]$, and of SS, NSS [kg/L] (eqs. (8) and (9)).

$$
\begin{aligned}
& P_{\mathrm{i}}=p_{\mathrm{i}} \cdot \frac{a}{A \cdot N} \cdot \frac{b}{A \cdot N_{\mathrm{SS}}}=p_{\mathrm{i}} \cdot \frac{a}{N} \cdot \frac{b}{N_{\mathrm{SS}}} \cdot \frac{1}{A^{2}} \\
& P_{\mathrm{r}}=p_{\mathrm{r}} \cdot \frac{a}{A \cdot N} \cdot \frac{b}{A \cdot N_{\mathrm{SS}}}=p_{\mathrm{r}} \cdot \frac{a}{N} \cdot \frac{b}{N_{\mathrm{SS}}} \cdot \frac{1}{A^{2}}
\end{aligned}
$$

where $P_{\mathrm{i}}[\mathrm{JPY} / \mathrm{L}]$ is the initial cost and $P_{\mathrm{r}}[\mathrm{JPY} / \mathrm{L}]$ is the running cost of a wastewater treatment facility that should treat wastewater containing oil and SS, respectively. $p_{\mathrm{i}}$ [JPY/L] and $p_{\mathrm{r}}[\mathrm{JPY} / \mathrm{L}]$ are the standard initial and running costs, respectively, of a wastewater treatment facility for the total amount of wastewater treated over the lifetime of the facility. In eqs. (8) and (9), $a / A>N$ and $b / A>N_{\text {ss }}$ are assumed to be true and $a[\mathrm{~kg} /$ day], $b$ [kg/day], and $A$ [L/day] are the amounts of oil and SS in the oil- and SScontaining wastewater per day, and the volume of the oiland SS-containing wastewater per day, respectively.

Recovering oil and SS from wastewater contributes to the reduction in the cost of a wastewater treatment facility. $h\left(X_{\mathrm{O} / \mathrm{Win}}\right)[\mathrm{JPY} / \mathrm{kg}]$ in eq. (10) represents the VF for the oiland SS-removed water and consists of the initial and running costs of the wastewater treatment facility without any oilwater separation and SS recovery equipment. $g\left(X_{\mathrm{O} / \text { wout }}\right)$ [JPY $/ \mathrm{kg}$ ] in eq. (11) represents the VF for the oil- and SScontaining wastewater and consists of the initial and running costs of a wastewater treatment facility with an oilwater separation and SS recovery equipment. Then $g\left(X_{\mathrm{O} / \mathrm{wout})}\right.$ [JPY/kg] was determined by adding the initial and running costs of the oil-water separation and SS recovery equipment to $h\left(X_{\mathrm{O} / \mathrm{Win}}\right)[\mathrm{JPY} / \mathrm{kg}] \cdot h\left(X_{\mathrm{W} / \mathrm{Win}}\right)[\mathrm{JPY} / \mathrm{kg}]$ and $g\left(X_{\mathrm{W} / \text { Wout }}\right)[\mathrm{JPY} /$ $\mathrm{kg}]$ were calculated by using eq. (3).

$$
\begin{aligned}
h\left(X_{\mathrm{O} / \mathrm{Win}}\right) & =-\frac{P_{\mathrm{i}}+P_{\mathrm{r}}}{\rho}=-\frac{\left(p_{\mathrm{i}}+p_{\mathrm{r}}\right) \cdot \rho}{N \cdot N_{\mathrm{SS}}} \cdot \frac{a}{A \rho} \cdot \frac{b}{A \rho} \\
& =-\frac{\left(p_{\mathrm{i}}+p_{\mathrm{r}}\right) \cdot \rho}{N \cdot N_{\mathrm{SS}}} \cdot X_{\mathrm{O} / \mathrm{Win}} \cdot X_{\mathrm{S} / \text { Win }} \\
g\left(W_{\mathrm{O} / \text { Wout }}\right) & =h\left(X_{\mathrm{O} / \text { Wout }}\right)-\frac{P_{\text {sep-oil }}+P_{\text {rec-SS }}+\left(E_{\text {sep-oil }}+E_{\text {rec-SS }}\right) \cdot \eta}{\rho}
\end{aligned}
$$

where, $\rho[\mathrm{kg} / \mathrm{L}]$ is the density of wastewater that changes with $X_{\mathrm{O} / \text { win. }} P_{\text {sep-oil }}[\mathrm{JPY} / \mathrm{L}]$ and $P_{\text {rec-ss }}[\mathrm{JPY} / \mathrm{L}]$ are the initial costs of oil-water separation and SS recovery equipment, respectively, for the amount of wastewater treated over the lifetime of the equipment. $E_{\text {sep-oil }}[\mathrm{kWh} / \mathrm{L}]$ and $E_{\text {rec-ss }}[\mathrm{kWh} / \mathrm{L}]$ are the input energy (electricity) of oil-water separation and SS recovery equipment, respectively, for the total amount of treated wastewater over the lifetime of the equipment. $\eta[\mathrm{JPY} / \mathrm{kWh}]$ is the conversion factor between cost and energy.

The field investigation data used to calculate SWU in the model restaurant are shown in Table 1. The initial cost of oil-water separation and SS recovery equipment included the product cost without the cost of installation. The running cost of oil-water separation and SS recovery equipment included the maintenance cost without the labor cost. Each initial cost was determined as one-tenth of the cost of the equipment installed on the actual factory because the treatment amount of wastewater in the model restaurant (3,000 L/day) was one-tenth of the actual factory capacity. The running cost of oil-water separation equipment was assumed to be same with the cost of the actual factory. The running cost of SS recovery equipment was 0 JPY/ month because the equipment was the filtration mesh that required no electricity or maintenance material.

Calculations were conducted by changing the separation ability of oil-water separation equipment. The recovery rate of SS recovery equipment was determined based on the results of the filtration experiments. Finally, all parameters regarding the oil- and SS-containing wastewater, the recovered oil, the recovered SS, and the oil- and SS-removed water were automatically determined based on the separation ability of oil-water separation equipment and the recovery rate of SS recovery equipment.

\section{Results and Discussion}

\subsection{Relationship between oil concentration rate of artificial wastewater and recovery rate of oil and SS by filtration}

Fig. 4 shows the viscosity of artificial wastewater with only sunflower oil with changing oil concentrations 
Table 1 Specific data for calculating Separative Work Unit (SWU) in model restaurant

\begin{tabular}{|c|c|c|}
\hline Variable & Value & Unit \\
\hline Heating value of fuel oil A & $39.1^{16)}$ & $\mathrm{MJ} / \mathrm{L}$ \\
\hline Price of fuel oil A & $90.7^{17)}$ & $\mathrm{JPY} / \mathrm{L}$ \\
\hline$V_{\text {heat }}$ & 0.00000232 & $\mathrm{JPY} / \mathrm{J}$ \\
\hline Heating value of sunflower oil & $9,200^{18)}$ & $\mathrm{kcal} / \mathrm{kg}$ \\
\hline$H_{\mathrm{oil}}$ & $37,656,000$ & $\mathrm{~J} / \mathrm{kg}$ \\
\hline$H_{\text {wat }}$ & $2,270,000^{19)}$ & $\mathrm{J} / \mathrm{kg}$ \\
\hline$a$ & $57^{*}$ & $\mathrm{~kg} /$ day \\
\hline$b$ & $3.3^{*}$ & $\mathrm{~kg} /$ day \\
\hline$A$ & $3,000^{*}$ & $\mathrm{~L} /$ day \\
\hline$N$ & $0.00003^{20)}$ & $\mathrm{kg} / \mathrm{L}$ \\
\hline$N_{\mathrm{SS}}$ & $0.00016^{20)}$ & $\mathrm{kg} / \mathrm{L}$ \\
\hline$P_{\text {sep-oil }}$ & $0.0791^{*}$ & $\mathrm{kWh} / \mathrm{L}$ \\
\hline$E_{\text {sep-oil }}$ & $0.000030^{*}$ & $\mathrm{kWh} / \mathrm{L}$ \\
\hline$P_{\text {rec-SS }}$ & $0.000244^{*}$ & $\mathrm{kWh} / \mathrm{L}$ \\
\hline$E_{\text {rec-SS }}$ & $0^{*}$ & $\mathrm{kWh} / \mathrm{L}$ \\
\hline$H$ & $17.08^{21)}$ & JPY/kWh \\
\hline Specific gravity of vegetable oil & $0.915^{22)}$ & - \\
\hline Specific gravity of water & 1 & - \\
\hline Specific gravity of SS & $1.6^{23)}$ & - \\
\hline \multicolumn{3}{|l|}{ Wastewater treatment facility } \\
\hline Lifetime & $15^{*}$ & year \\
\hline Initial cost & $6,000,000^{*}$ & JPY \\
\hline Running cost & $30,721^{*}$ & JPY/month \\
\hline \multicolumn{3}{|l|}{ Oil-water separation equipment } \\
\hline Lifetime & $15^{*}$ & year \\
\hline Initial cost & $1,300,000^{*}$ & JPY \\
\hline Running cost & $1.35^{*}$ & JPY/month \\
\hline \multicolumn{3}{|l|}{ SS recovery equipment } \\
\hline Lifetime & $15^{*}$ & year \\
\hline Initial cost & $4,000^{*}$ & JPY \\
\hline Running cost & $0^{*}$ & JPY/month \\
\hline
\end{tabular}

Values marked * were obtained through field investigations

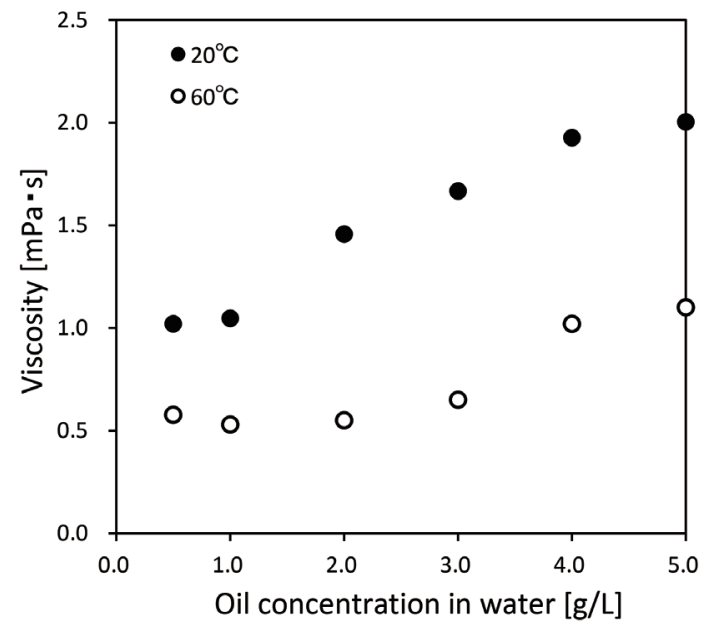

Fig. 4 Viscosity of artificial wastewater with changing oil concentrations used in the filtration experiments at $20^{\circ} \mathrm{C}$ and $60^{\circ} \mathrm{C}$ at $20^{\circ} \mathrm{C}$ and $60^{\circ} \mathrm{C}$. Fig. 5 shows the viscosity of artificial wastewater with only flour as SS with changing SS concentrations at $20^{\circ} \mathrm{C}$ and $60^{\circ} \mathrm{C}$. Although the viscosity of artificial wastewater with SS was almost constant regardless of the SS concentration, the viscosity of artificial wastewater with oil gradually increased with increasing oil concentration in wastewater. This result suggests that oil concentration in water has a greater effect on the viscosity of wastewater than the SS concentration. Moreover, higher water temperatures were associated with lower viscosity values.

One of results of the filtration experiments with artificial wastewater at $20^{\circ} \mathrm{C}$ and with $0.5 \mathrm{~g} / \mathrm{L}$ of oil concentration are shown in Fig. 6. Although artificial wastewater was assumed to be the oil-removed wastewater,

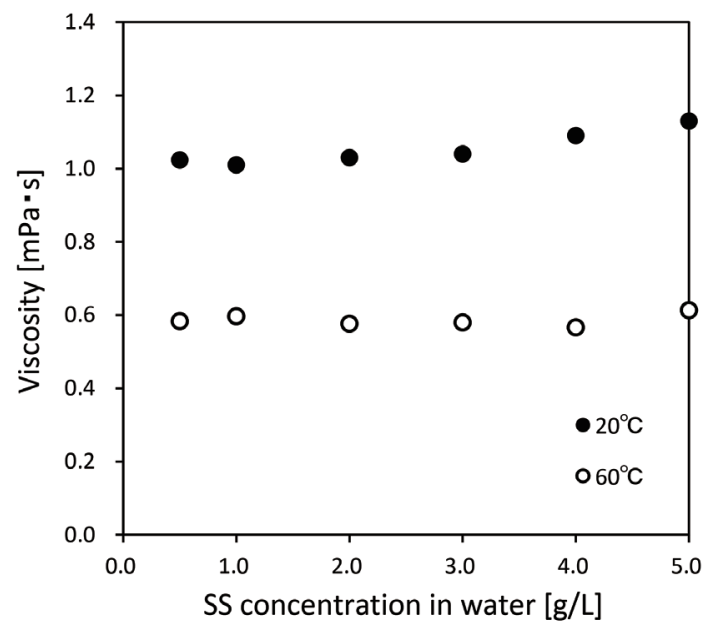

Fig. 5 Viscosity of artificial wastewater with changing SS concentrations used in the filtration experiments at $20^{\circ} \mathrm{C}$ and $60^{\circ} \mathrm{C}$

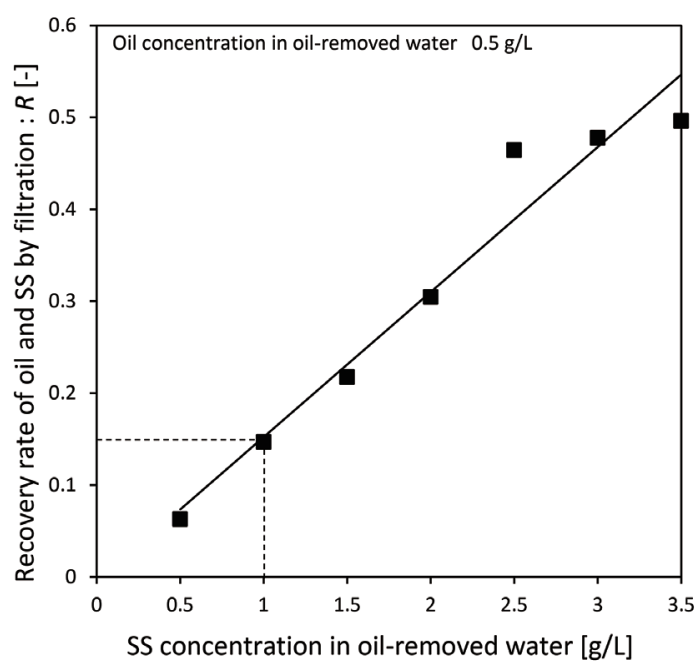

Fig. 6 Relationship between SS concentration in oil-removed water and recovery rate of oil and SS by filtration: $R[-]$ $\left(20^{\circ} \mathrm{C}\right.$; oil concentration in oil-removed water $\left.0.5 \mathrm{~g} / \mathrm{L}\right)$ 
Table 2 Values of fitted curves elucidated by the filtration experiments with artificial wastewater at $20^{\circ} \mathrm{C}$ and $60^{\circ} \mathrm{C}$

\begin{tabular}{rlr}
\hline $\begin{array}{c}\text { Oil concentration in } \\
\text { oil-removed water } \\
{[\mathrm{g} / \mathrm{L}]}\end{array}$ & Fitted curve & $\begin{array}{c}\text { Coefficient of } \\
\text { determination }\end{array}$ \\
\hline $20^{\circ} \mathrm{C}$ : Temperature of artificial wastewater & \\
\hline 0.5 & $y=0.1577 x-0.0054$ & 0.9524 \\
\hline 1.0 & $y=0.1117 x+0.024$ & 0.8660 \\
\hline 1.5 & $y=0.0707 x+0.0181$ & 0.8218 \\
\hline 2.0 & $y=0.0280 x+0.0749$ & 0.7375 \\
\hline 2.5 & $y=0.0381 x+0.051$ & 0.7573 \\
\hline 3.0 & $y=0.0603 x+0.014$ & 0.9537 \\
\hline $60^{\circ} \mathrm{C}$ : Temperature of artificial wastewater & \\
\hline 0.5 & $y=-0.0048 x+0.3135$ & 0.0089 \\
\hline 1.0 & $y=0.0751 x+0.1339$ & 0.7989 \\
\hline 1.5 & $y=0.0717 x+0.1149$ & 0.8599 \\
\hline 2.0 & $y=0.0785 x+0.0551$ & 0.5120 \\
\hline 2.5 & $y=0.0235 x+0.1302$ & 0.4965 \\
\hline 3.0 & $y=0.0335 x+0.0918$ & 0.7939 \\
\hline
\end{tabular}

$x$ : SS concentration in oil-removed water $[\mathrm{g} / \mathrm{L}]$

$y$ : Recovery rate of oil and SS by filtration: $R[-]$

depending on the separation ability of oil-water separation equipment, residual oil concentration in wastewater was determined. Then, the filtration experiments were conducted for each residual oil concentration in wastewater. Fitted curves explained the relationship between the SS concentration in artificial oil-removed wastewater and the recovery rate of oil and SS by filtration $(R[-]$ : defined in eq. (1)). Other results of the filtration experiments at $20^{\circ} \mathrm{C}$ and $60^{\circ} \mathrm{C}$ are listed in Table 2. Under all oil concentrations (0.5$3.0 \mathrm{~g} / \mathrm{L}), R[-]$ linearly increased at higher SS concentrations. Here, 0.318 of $R[-]$ was achieved as the average value at 60 ${ }^{\circ} \mathrm{C}, 0.5 \mathrm{~g} / \mathrm{L}$ of $\mathrm{n}$-hexanes extract, and $0.5 \mathrm{~g} / \mathrm{L}$ of SS by using actual wastewater from the cafeteria of the University of Tsukuba in December 2016. n-hexanes and SS concentration were measured once every hour for three hours, and $R$ [-] was measured from the result of the nine filtration experiments. Compared to this result, the value of $R[-]$ by artificial wastewater (at $60^{\circ} \mathrm{C}, 0.5 \mathrm{~g} / \mathrm{L}$ of oil concentration) calculated as 0.311 from Table 2 was enough close.

In the model restaurant, oil concentration in the oilremoved water was $1 \mathrm{~g} / \mathrm{L}$ ( $1 \mathrm{~g}$ of oil per $1 \mathrm{~L}$ of water). Thus, $R$ [-] based on the oil concentration of $1 \mathrm{~g} / \mathrm{L}$ after the oil removal was chosen to explain the relationship between the oil concentration in the oil-removed water and $R[-]$ at $20^{\circ} \mathrm{C}$ (Fig. 7) and $60^{\circ} \mathrm{C}$ (Fig. 8). $R$ [-] at $20^{\circ} \mathrm{C}$ and $60^{\circ} \mathrm{C}$ decreases with increasing oil concentration in the oil-removed water. This result suggests that high SS recovery performance by filtration can be obtained by reducing the oil concentration in wastewater. Increasing oil concentration in the oilremoved water inhibited the collection of SS on the mesh

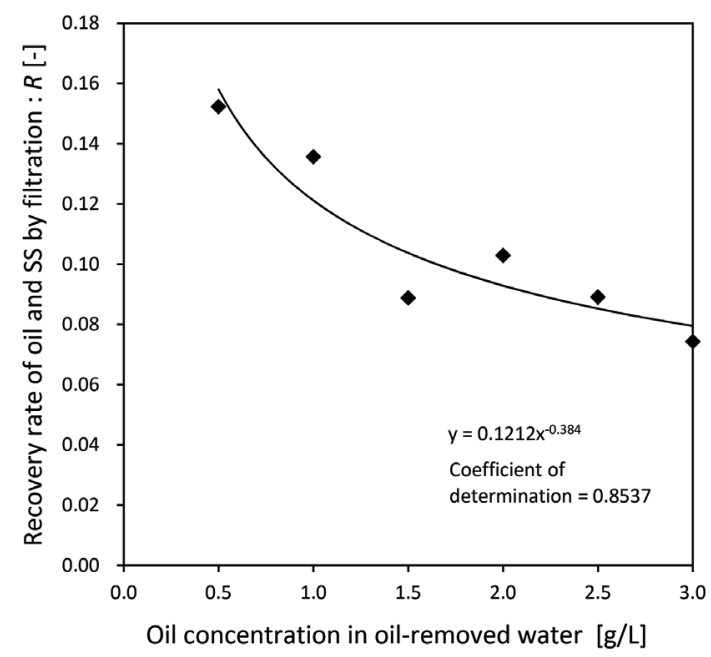

Fig. 7 Oil concentration in oil-removed water and recovery rate of oil and SS by filtration: $R[-]\left(20^{\circ} \mathrm{C}\right)$ (SS concentration $1 \mathrm{~g} / \mathrm{L})$

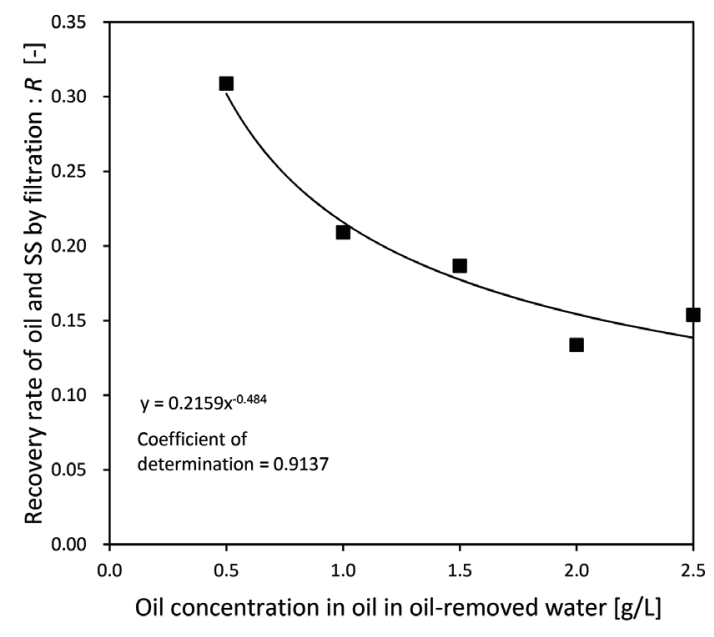

Fig. 8 Oil concentration in oil-removed water and recovery rate of oil and SS by filtration : $R[-]\left(60^{\circ} \mathrm{C}\right)(\mathrm{SS}$ concentration 1 $\mathrm{g} / \mathrm{L})$

because SS were wrapped in oil and passed through the mesh with the oil due to its high viscosity.

\subsection{Separation ability of oil-water separation and the recovery rate of SS recovery equipment}

By changing the separation ability of oil-water separation equipment from 0 to $100 \%$ in steps of $5 \%$, the oil concentration in the oil-removed water was determined. Based on this concentration and the results of Figs. 7 and $8, R[-]$ in SS recovery equipment downstream of oil-water separation equipment was determined. Fig. 9 shows the relationship between the separation ability of oil-water separation equipment and $R$ [-] in SS recovery equipment with wastewater at $20^{\circ} \mathrm{C}$ and $60^{\circ} \mathrm{C}$. Here, $R$ [-] described in eq. (1) was equal to the recovery rate of SS recovery 


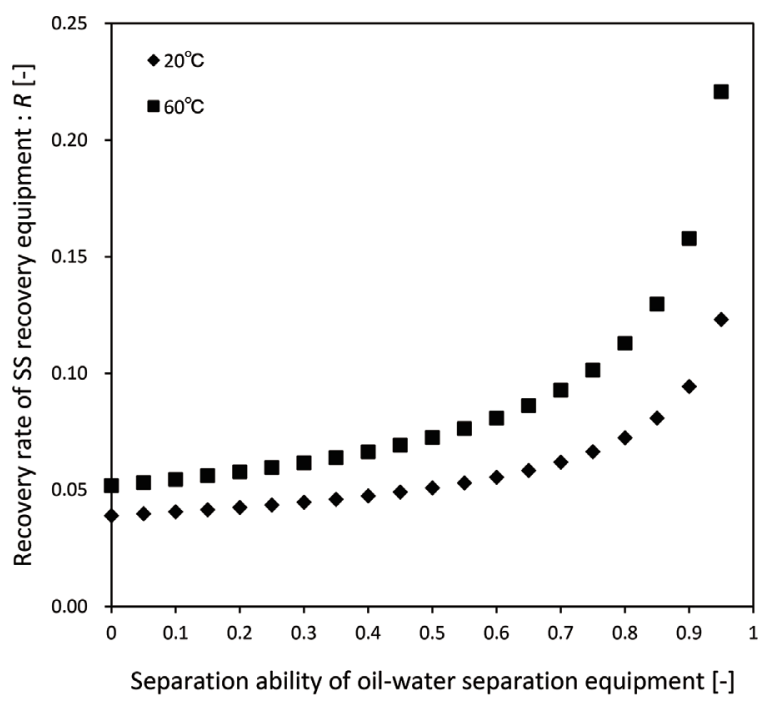

Fig. 9 Separation ability of oil-water separation equipment and recovery rate of SS recovery equipment: $R[-]$

equipment.

At both $20^{\circ} \mathrm{C}$ and $60^{\circ} \mathrm{C}, R[-]$ exponentially increases with higher separation ability of oil-water separation equipment. SS recovery equipment with low input energy and high recovery rate can be developed. Decreasing the mesh opening size would increase $R[-]$, but can lead to increased clogging of the mesh. A proper size of the mesh opening should be selected for each restaurant, to enable low maintenance costs and sustainable use of SS recovery equipment.

$R$ [-] of wastewater at $60^{\circ} \mathrm{C}$ was higher than that at $20^{\circ} \mathrm{C}$. The difference in $R$ [-] between $20^{\circ} \mathrm{C}$ and $60^{\circ} \mathrm{C}$ increases with higher separation ability of oil-water separation equipment. Therefore, from the viewpoint of recovering oil and SS by filtration equipment, heating wastewater is an effective way of increasing the recovery rate of SS recovery equipment and decrease the contaminants in the treated water.

\subsection{Trial calculation of SWU}

The relationship between the separation ability of oil-water separation and the recovery rate of SS recovery equipment from the results of our filtration experiments was used to calculate the SWU for combination use at $20^{\circ} \mathrm{C}$ (Fig. 10) and $60^{\circ} \mathrm{C}$ (Fig. 11). The SWU for single use is also shown in Figs. 10 and 11.

At $20^{\circ} \mathrm{C}$ and $60^{\circ} \mathrm{C}$, the SWU for single use increases linearly with the increasing separation ability of oil-water separation equipment. However, the SWU for combination use increases logarithmically with the increasing separation ability. Regardless of the separation ability of oil-water separation equipment, the SWU for combination use is

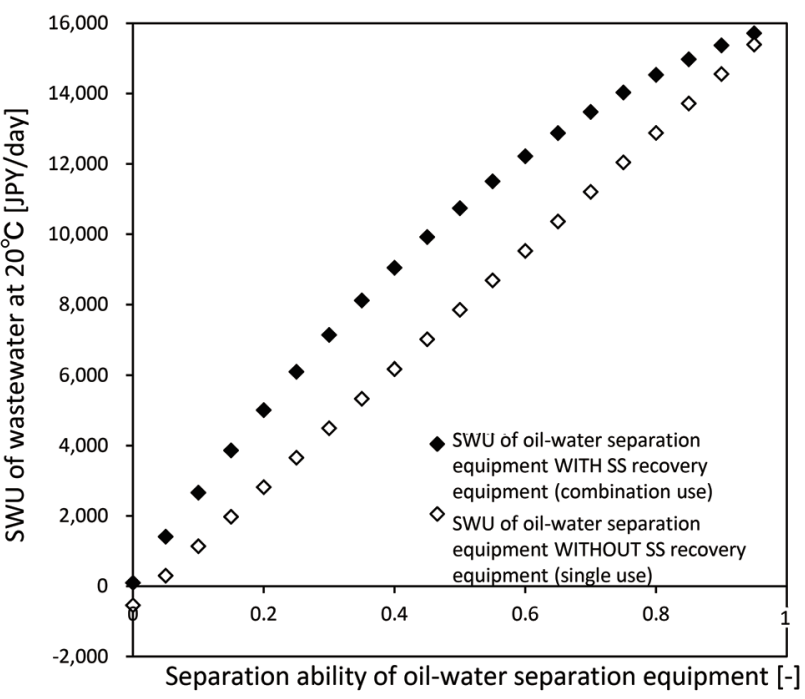

Fig. 10 Relationship between separation ability of oil-water separation equipment and SWU for combination and single use at $20^{\circ} \mathrm{C}$

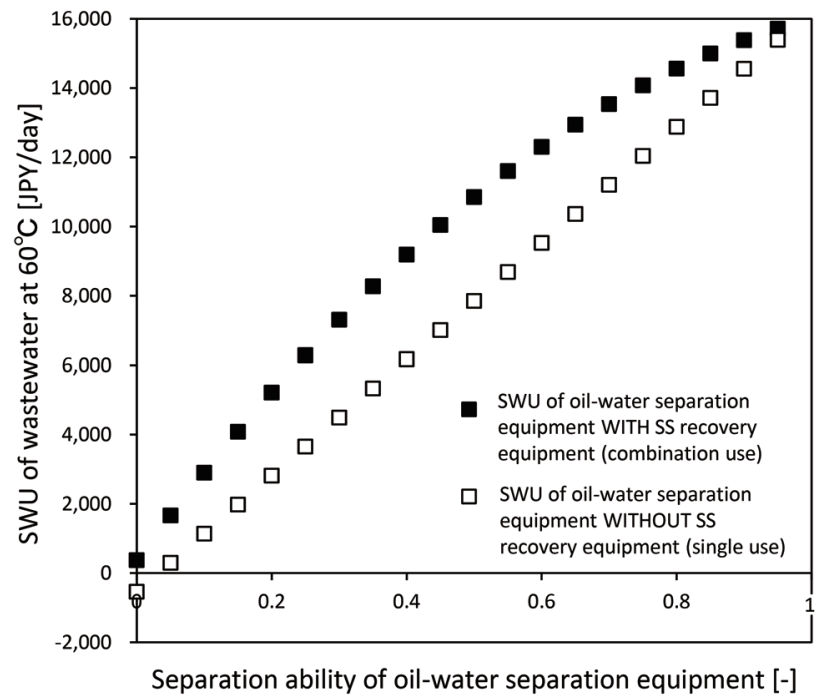

Fig. 11 Relationship between separation ability of oil-water separation equipment and SWU for combination and single use at $60^{\circ} \mathrm{C}$

always higher than that for single use.

At 0\% separation ability, the SWU for single use is negative, meaning that installing oil-water separation equipment would be economically undesirable. Above 5\% separation ability, the SWU for single use becomes positive indicating that even with low separation ability, installing oil-water separation equipment would be economically feasible. On the other hand, the SWU for combination use is positive for all separation ability value.

In addition, Fig. 12 illustrates the relationship between the separation ability of oil-water separation equipment and the difference in the SWU between combination and single uses that shows the effectiveness 


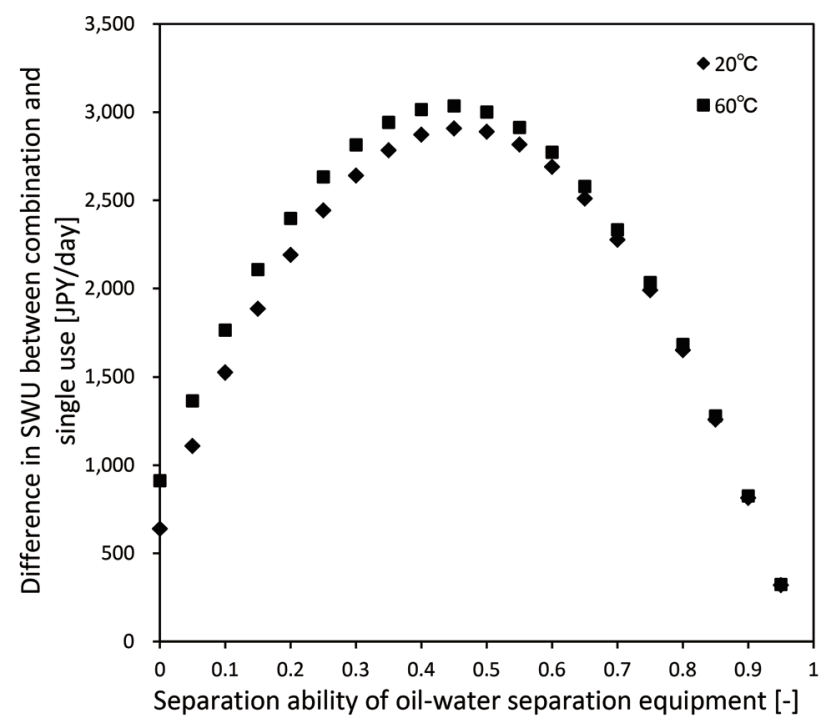

Fig. 12 Separation ability of oil-water separation equipment and difference in SWU between combination and single uses

of adding SS recovery equipment downstream of oil-water separation equipment (maximum value on $45 \%$ separation ability, $539 \mathrm{JPY} /$ day at $20^{\circ} \mathrm{C}$ and $562 \mathrm{JPY} /$ day at $60^{\circ} \mathrm{C}$ ). The difference decreases toward $0 \%$ and $95 \%$ separation abilities. The minimum difference at 95\% separation ability was $58 \mathrm{JPY} /$ day at both $20^{\circ} \mathrm{C}$ and $60^{\circ} \mathrm{C}$.

At both $20^{\circ} \mathrm{C}$ and $60^{\circ} \mathrm{C}$, the difference between the SWU for combination and single uses is positive, meaning that installing both oil-water separation and SS recovery equipment has a positive economic effect.

Fig. 13 shows the relationship between the separation ability of oil-water separation equipment and the difference in the SWU for combination use at $20^{\circ} \mathrm{C}$ and $60^{\circ} \mathrm{C}$ that shows the effectiveness of heating wastewater. The difference decreases with increasing the separation ability of oil-water separation equipment. The maximum difference in the SWU for combination use at $20^{\circ} \mathrm{C}$ and $60^{\circ} \mathrm{C}$ is 273 JPY/day at $0 \%$ separation ability and the minimum is 11 JPY/day at 95\% separation ability.

Increasing the wastewater temperature from $20^{\circ} \mathrm{C}$ to $60^{\circ} \mathrm{C}$ did not change the SWU significantly if the separation ability of oil-water separation equipment was maintained. However, regardless of the separation ability, the difference in the SWU between combination and single uses is positive, meaning that heating wastewater is economically feasible.

At the actual factory, wastewater that flowed into oilwater separation equipment was at a temperature of about $60^{\circ} \mathrm{C}$ and thus it needed not be heated before treatment. In general, the recovery rate of oil and SS in wastewater from factories can be improved by heating wastewater upstream before releasing it into a wastewater treatment facility.

In this study, the effect of the SWU on installing

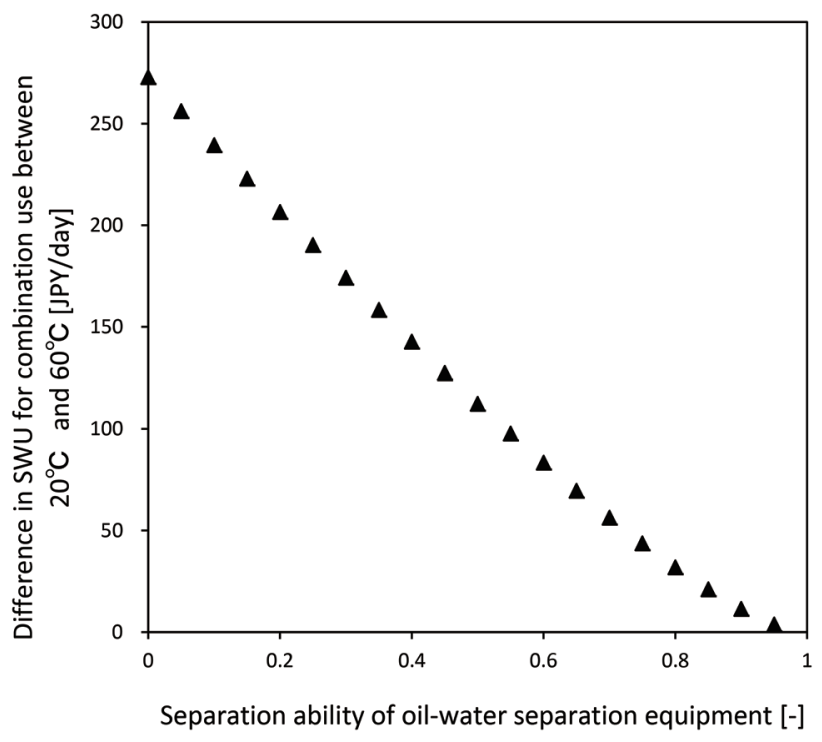

Fig. 13 Separation ability of oil-water separation equipment and difference in SWU for combination use between $20^{\circ} \mathrm{C}$ and $60^{\circ} \mathrm{C}$

both oil-water separation and SS recovery equipment (combination use) was not high because the amount of wastewater was relatively small. If the relationship between the oil concentration in the oil-removed water and the recovery rate of oil and SS by filtration, $R$ [-], such as in Figs. 7-9, is applied to animal fat instead of vegetable oil, the SWU of food processing factories, restaurants, and food shops that discharged a large amount of wastewater would be significantly greater. This is because the profit from increasing the amount of the recovered oil and decreasing wastewater treatment costs would be larger than the initial and running costs of installing oil-water separation and SS recovery equipment.

\section{Conclusions}

1) To explain the effect of installing oil-water separation and SS recovery equipment for wastewater treatment at a restaurant or food shop, an economic evaluation by SWU was conducted for two cases: using oil-water separation equipment without SS recovery equipment (single use) and using oil-water separation equipment with SS recovery equipment (combination use).

2) Filtration experiments with artificial wastewater explained the relationship between the input amount of SS in the oil-removed water and the recovery rate of oil and SS by filtration, $R[-]$, at $20^{\circ} \mathrm{C}$ and $60^{\circ} \mathrm{C}$. The separation ability of oil-water separation equipment could determine the required $R[-]$ of SS recovery equipment.

3) The SWU for combination use at $20^{\circ} \mathrm{C}$ and $60^{\circ} \mathrm{C}$ was higher than the SWU for single use. The SWU for combination use at $60^{\circ} \mathrm{C}$ was higher than that at $20^{\circ} \mathrm{C}$. 
At $60^{\circ} \mathrm{C}$, combination use increased the SWU by 562 JPY/day compared to single use, at 45\% separation ability of oil-water separation equipment according to the results of our filtration experiments.

\section{Acknowledgement}

This work was supported by JSPS KAKENHI Grant Number JP 26450351.

\section{References}

1) Otsuka, T.; Ankyu, E.; Noguchi R., The society of Eco-Engineering 2013, 29-30 June 2013 (Tamagawa University, Tokyo, Japan)

2) Noguchi, Y.; Nishimura, O.; Asakawa, S.; Yamagishi, T.; Ootsuka, T., Journal of Water and Waste, 54, 849-859 (2012)

3) Sugimori, D., Bulletin of the Society of Sea Water Science, Japan, 65, 272-279 (2011)

4) Ryuda, N.; Yokobori, K.; Inoue, A.; Annoura, K.; Teshima, I.; Ueno, D.; Inoue, K.; Someya, T., Journal of Environmental conservation engineering, 38(11), 41-49 (2009)

5) Kurozumi, S.; Kitamura, T.; Tunota, J.; Izumi, Y.; Kurane, R., Japan Journal of Food Engineering, 6(4), 245251 (2005)

6) Fujii, E.; Tunematsu, T.; Kamimoto, Y.; Kohda, J.; Suehara, K.; Nakano, Y.; Yano, T., Japan Journal of Food Engineering, 4(4), 123-128 (2003)

7) Otsuka, T.; Ankyu, E.; Noguchi, R., Agricultural Information Research, 25, 29-38 (2016)

8) Ministry of the Environment, https://www.env.go.jp/ policy/etv/pdf/list/h21/020-0902b.pdf, (Last access: 2016.09.27)

9) Ankyu, E.; Otsuka, T.; Noguchi, R., J. Jpn. Inst. Energy, 95(3), 275-282 (2016)

10) Editional committee of food science handbook, Food science handbook, Kyoritsu Shuppan Co. Ltd., 1978

11) Fuchs, K.; Peierls, R., Separation of Isotopes, Selected Scientific Papers of Sir Rudolf Peierls: With Commentary (Dalitz, R.H. and S. R. Peierls). World Scientific series in 20th century physics, World Scientific, 19, 303-320, 1997

12) Takeda, K., Mechanism of separation -Latest separation, Kyoritsu Shuppan Co. Ltd., 1988

13) Bernstein, J., SWU for U and ME, Cornell University Library, 2009

14) Matsumura, H., Journal of JOHKASOU, 442, 29-31 (2013)

15) Otsuka, T.; Noguchi, R., Journal of JOHKASOU, 479, 1013 (2016)

16) Ministry of Economy, Trade and Industry, http://www. enecho.meti.go.jp/statistics/total_energy/pdf/stte_012. pdf, (Last access: 2016.09.27)

17) Ministry of Economy, Trade and Industry, http://www. enecho.meti.go.jp/statistics/petroleum_and_lpgas/pl007/ results.html\#headline3, (Last access: 2016.09.27)

18) USDA National Nutrient Database for Standard Reference Release 28, https://ndb.nal.usda.gov/ndb/ foods $/$ show $/ 720$ ? manu $=\& f g c d=\& d s=$, (Last access: 2016.09.27)

19) Japan Society for Food Engineering, Ed., Food Engineering, Asakura Publishing Co., Ltd., pp. 110, 2012

20) Ministry of the Environment, http://www.kankyo. metro.tokyo.jp/water/pollution/regulation/emission_ standard/general.html, (Last access: 2016.09.27)

21) Hokuriku Electric Power Company, http://www. rikuden.co.jp/ryokin/syoutenkoujyou.html\#38, (Last access: 2016.09.27)

22) Satoshi Fujita, Food technology Food fat and oil, and their applications, Saiwai shobo, pp. 89, 2011

23) Hayashi Syoten Co, Ltd., http://www.hayashisyoten. co.jp/39/228/, (Last access: 2016.09.27) 